\title{
KAUNO KELIONIŲ AGENTŪRŲ INTERNETO TINKLALAPIŲ VERTINIMAS
}

\author{
Diana Komskienė, Aistė Kotkevičiūtė \\ Lietuvos sporto universitetas, Kaunas, Lietuva
}

\begin{abstract}
ANOTACIJA
Tiriant Kauno kelionių agentūrų interneto tinklalapius siekta nustatyti, kaip juos vertina paslaugu vartotojai. Vertinimui buvo pasirinkti esminiai turizmo paslaugos rinkimosi ir pirkimo elektroninejje erdvejje kriterijai, turintys itakos vartotojų pasirinkimui: patogumas, kokybè, kaina, valdymas, dizainas, bendravimas. Tyrimas atskleidè svarbiausius turizmo paslaugu pasiūlos interneto tinklalapiuose kriterijų bruožus, tokius kaip dizainas, bendravimas, saugumas. Šie kriterijai padeda formuoti vartotoju ipročius, susivokti, o kelioniu agentūroms - patraukliai teikti turizmo paslaugų pasiūlą ir sẻkmingai konkuruoti rinkoje.
\end{abstract}

Raktiniai žodžiai: turizmo paslauga, paslaugos rinkimasis ir pirkimas, interneto tinklalapiai, kelionių agentūros.

\section{IVADAS}

Tyrimo aktualumas. Šiuolaikinė rinka nuolat kinta, ir šie pokyčiai yra glaudžiai susiję su vartotojų elgsena. Atlikdama vartotojų elgsenos tyrimus ir taikydama tai praktikoje, organizacija gali sèkmingai konkuruoti rinkoje, pritraukti ir išlaikyti vartotojus. Vartotojų elgseną nusako ne tik prekių ir paslaugų pirkimas, bet ir jų elgsena per visą pirkimo procesą, kuriam būdingi pagrindiniai etapai: informacijos paieška, alternatyvų ivertinimas, pasirinkimas. Socialiniai ir psichologiniai veiksniai bei individualūs skirtumai nusako vartotojo, kaip turisto, elgesị, kurị lemia jo asmenybė, gyvenimo būdas ir patirtis. Turizmo paslaugu vartotojų elgsena priklauso nuo vartotojų tipų. Dẻl to dauguma organizacijų išvystė veiklą elektroninëje erdvejje, kad gebėtų išlikti konkurencijos sąlygomis. Šiuo metu dar trūksta mokslinių tyrimų, analizuojančių vartotojų elgseną interneto erdvejje pagal poreikius nuolat kintančioje rinkoje.

Vienas iš žingsnių elektroninèje erdvèje yra tinklalapio kūrimas. Organizacijoms svarbu turèti nepriekaištingą tinklalapi, nes jo kokybe turi itakos vartotoju pasirinkimui pirkti elektroninëje erdvejje. Daugelio mokslininkų teigimu (Jalilvand et al., 2013; Trocchia, Janda, 2003; Guseva, 2010; Bukhari, 2013; Constantinides, 2004; Davidavičienė, Tolvaišas, 2011; Tucker, 2008; Law, 2007; Castaneda et al., 2008; Liu, 2012; Bakanauskas, Liesionis, 2008; Martin, Camarero, 2008; Ozen, Engizek, 2013), interneto tinklalapiai vartotojų elgsenos aspektu tampa vis svarbesniu organizacijų tyrimo objektu.

Pagrindiniai turizmo paslaugos rinkimosi ir pirkimo elektroninèje erdvèje kriterijai yra susiję su valdymu, patogumu, naudojimosi paprastumu, saugumu, patikimumu, dizaino patrauklumu, greičiu ir mažesne kaina, taip pat galimybe bendrauti, būti interaktyviems. Elektroninès erdvès pritaikomumas šiems poreikiams suteikia turizmo vartotojams pasitenkinimą ir naudą, atskleidžia vadybininkams elektroninès erdvès dermès su vartotoju poreikiais galimybes (Komskienè, Kotkevičiūtè, 2014).

Tyrimo tikslas - įvertinti Kauno kelionių agentūrų interneto tinklalapius.

Tyrimo objektas - Kauno kelionių agentūrų interneto tinklalapių vertinimas. 
Tyrimo organizavimas. Pirmas žingsnis - vertinimo kriterijų taikymas pagal mokslinès studijos šaltinị. Antras žingsnis - Kauno kelionių agentūrų imties nustatymas. Trečias žingsnis duomenų analizè ir vertinimas pagal nustatytus turinio analizès kriterijus.

\section{Tyrimo metodai}

Tyrimui pasirinkta turinio (angl. content) analizè, pagrista interpretacija. Tai leido įvertinti kelionių agentūrų interneto tinklalapius vartotojų požiūriu. Pasak V. Žydžiūnaitès (2007), turinio analizès tikslas - informacijos masyve identifikuoti prasminius tyrimo vienetus.

Turinio analizès darbo metodai yra šie (Žydžiūnaitė, 2005): 1) daugkartinis teksto skaitymas; 2) manifestinių kategorijų išskyrimas remiantis raktažodžiais; 3) kategorijų turinio skaidymas i subkategorijas; 4) tinklalapių vertinimas pagal nustatytus kriterijus skalèje nuo 1 (labai blogai) iki 5 (labai gerai); 5) kategorijų ir subkategorijų interpretavimas.

Prieš pradedant tyrimus, labai svarbu nustatyti reikalingą minimalų tyrimų skaičių, kad būtų galima padaryti reikšmingas išvadas (Kardelis, 2002). Lietuvos statistikos departamentas neteikia duomenu apie kelionių agentūrų skaičių ir veiklą Kauno mieste, todèl buvo kreiptasi i Kauno turizmo informacijos centrą ir konferencijų biurą. Centro duomenimis, 2014 m. kovo mènesi Kaune veikè 22 išvykstamojo turizmo paslaugas teikiančios kelionių agentūros. Šiuo atveju turinio analizès imti sudare 22 Kauno miesto kelionių agentūrų interneto tinklalapiai.

Pritaikius tyrime „Vartotojų elektroninės erdvės vertinimas pagal poreikius“ (Komskienè, Kotkevičiūtè, 2014) nustatytus vertinimo kriterijus, gautos 7 kategorijos (saugumas, patogumas, estetika, kompetentingumas, bendradarbiavimas, kokybè, nuolaidos) ir 24 subkategorijos, pagristos teiginiais, rodančiais jų svarbumą.

Siekiant išlaikyti anonimiškumą, kelionių agentūros buvo užkoduotos raidèmis nuo A iki X, o interneto tinklalapiai vertinti remiantis minètais kriterijais.

\section{REZULTATAI IR APTARIMAS}

Kriterijai buvo nustatyti remiantis moksline literatūra ir vartotojų elgsenos tyrimais. 22 Kauno miesto kelionių agentūrų tinklalapiai buvo ivvertinti pagal sudarytas kategorijas ir subkategorijas skalèje nuo 1 (labai blogai) iki 5 (labai gerai) (1 lentelè).

Tyrimo rezultatai parodè, kad tarp kelionių agentūrų tinklalapių yra esminių panašumų ir skirtumų. Panašumų turèjo agentūrų A, B ir C tinklalapiai. Šių agentūrų tinklalapiams trūksta estetikos (vertinimo vidurkis - 1,7), tačiau labai gerai įvertintas jų saugumas $(4,2)$ ir kokybė $(4,7$ ir 5). Reikšmingi vidurkiai nustatyti vertinant $D$ ir E agentūrų tinklalapius: jų estetika îvertinta labai gerai (5), o saugumas - blogai (2,2 ir 2,6). Visos minètos agentūros nuolaidų neteikia (1).

Agentūroms F, G, H, I, J, K, L, M, N būdinga kompetentingumas (aptarnavimo) ir bendradarbiavimas (nuo 4 iki 5). Jų tinklalapiai ịvertinti kaip labai saugūs (nuo 4,7 iki 5), o tai lemia agentūrų pranašumą interneto erdvèje.

Agentūrų $\mathrm{M}$ ir $\mathrm{N}$ tinklalapių bendras vertinimo pagal visus kriterijus (saugumas, patogumas, estetika, kompetentingumas, bendravimas, kokybė, nuolaidos) vidurkis yra labai mažas - nuo 1 iki 3,4.

Agentūrų $\mathrm{O}$ ir $\mathrm{P}$ interneto tinklalapiai atitinka visus keliamus reikalavimus (vertinimo vidurkiai - nuo 4 iki 5). Tačiau ir šios agentūros nuolaidų neteikia. 
1 lentelè. Kelionių agentūrų tinklalapių vertinimas

\begin{tabular}{|c|c|c|c|c|c|c|c|c|c|c|c|c|c|c|c|c|c|c|c|c|c|c|c|}
\hline \multirow{2}{*}{ Kategorija } & \multirow{2}{*}{ Subkategorija } & \multicolumn{22}{|c|}{ AGENTŪROS } \\
\hline & & $\mathrm{A}$ & $B$ & $\mathrm{C}$ & $\mathrm{D}$ & $E$ & $\mathrm{~F}$ & $G$ & $\mathrm{H}$ & 1 & $\mathrm{~J}$ & $\mathrm{~K}$ & $\mathrm{~L}$ & $\mathrm{M}$ & $\mathrm{N}$ & 0 & $\mathrm{P}$ & $R$ & $\mathrm{~S}$ & $\mathrm{~T}$ & $\mathrm{U}$ & $\mathrm{V}$ & $x$ \\
\hline \multirow{5}{*}{ Saugumas } & $\begin{array}{l}\text { Kelionès } \\
\text { paketas }\end{array}$ & 5 & 5 & 5 & 2 & 3 & 5 & 5 & 5 & 5 & 5 & 5 & 5 & 2 & 5 & 5 & 5 & 5 & 5 & 4 & 5 & 5 & 5 \\
\hline & $\begin{array}{l}\text { Kliento } \\
\text { duomenys }\end{array}$ & 5 & 5 & 5 & 2 & 2 & 5 & 5 & 5 & 5 & 2 & 5 & 5 & 2 & 5 & 5 & 5 & 2 & 5 & 4 & 5 & 5 & 5 \\
\hline & $\begin{array}{l}\text { Informacijos } \\
\text { patikimumas }\end{array}$ & 5 & 5 & 5 & 5 & 5 & 2 & 5 & 5 & 5 & 5 & 5 & 5 & 3 & 5 & 5 & 5 & 5 & 5 & 4 & 5 & 5 & 5 \\
\hline & $\begin{array}{l}\text { Grąžinimo } \\
\text { garantas }\end{array}$ & 1 & 1 & 1 & 1 & 1 & 4 & 4 & 5 & 4 & 2 & 5 & 4 & 2 & 5 & 5 & 2 & 2 & 3 & 2 & 5 & 4 & 5 \\
\hline & Apmokèjimas & 5 & 5 & 5 & 1 & 2 & 1 & 5 & 5 & 5 & 5 & 5 & 5 & 5 & 5 & 1 & 5 & 5 & 3 & 5 & 5 & 5 & 5 \\
\hline \multirow{7}{*}{ Patogumas } & Valdymas & 3 & 3 & 2 & 5 & 5 & 5 & 5 & 5 & 2 & 5 & 4 & 4 & 1 & 2 & 5 & 3 & 2 & 3 & 4 & 4 & 5 & 5 \\
\hline & Greitis & 5 & 5 & 5 & 5 & 5 & 5 & 5 & 5 & 5 & 5 & 5 & 5 & 5 & 5 & 5 & 5 & 3 & 5 & 5 & 5 & 5 & 5 \\
\hline & Prieinamumas & 5 & 5 & 5 & 5 & 5 & 5 & 5 & 5 & 5 & 5 & 5 & 5 & 5 & 5 & 5 & 5 & 3 & 3 & 4 & 5 & 5 & 5 \\
\hline & Interaktyvumas & 5 & 5 & 2 & 4 & 5 & 2 & 3 & 2 & 2 & 5 & 5 & 2 & 1 & 3 & 5 & 5 & 5 & 5 & 3 & 5 & 5 & 5 \\
\hline & Apmokèjimas & 5 & 1 & 1 & 1 & 2 & 1 & 5 & 2 & 5 & 5 & 2 & 1 & 1 & 2 & 1 & 5 & 4 & 3 & 1 & 5 & 5 & 5 \\
\hline & $\begin{array}{l}\text { Nesuvaržytas } \\
\text { darbo laikas }\end{array}$ & 5 & 5 & 5 & 1 & 5 & 1 & 5 & 1 & 5 & 5 & 3 & 1 & 1 & 4 & 4 & 4 & 4 & 3 & 4 & 5 & 5 & 5 \\
\hline & Išdėstymas & 3 & 5 & 3 & 5 & 5 & 1 & 3 & 3 & 1 & 5 & 3 & 2 & 2 & 3 & 5 & 4 & 3 & 2 & 4 & 5 & 5 & 5 \\
\hline \multirow[b]{2}{*}{ Estetika } & Dizainas & 2 & 2 & 2 & 5 & 5 & 4 & 2 & 4 & 3 & 5 & 3 & 4 & 2 & 1 & 4 & 4 & 4 & 5 & 4 & 3 & 5 & 3 \\
\hline & $\begin{array}{l}\text { Vizualus } \\
\text { patrauklumas }\end{array}$ & 1 & 1 & 1 & 5 & 5 & 4 & 2 & 4 & 3 & 5 & 3 & 4 & 2 & 1 & 4 & 4 & 4 & 5 & 4 & 3 & 5 & 3 \\
\hline $\begin{array}{l}\text { Kompeten- } \\
\text { tingumas }\end{array}$ & Aptarnavimas & 3 & 4 & 4 & 5 & 3 & 4 & 4 & 5 & 5 & 5 & 4 & 4 & 3 & 1 & 5 & 4 & 4 & 5 & 5 & 4 & 5 & 4 \\
\hline \multirow{4}{*}{$\begin{array}{l}\text { Bendradar- } \\
\text { biavimas }\end{array}$} & Bendravimas & 4 & 4 & 4 & 5 & 5 & 3 & 4 & 3 & 3 & 5 & 4 & 4 & 3 & 1 & 5 & 4 & 4 & 5 & 5 & 5 & 5 & 5 \\
\hline & Personalizavimas & 2 & 4 & 2 & 4 & 4 & 3 & 4 & 3 & 3 & 5 & 4 & 4 & 3 & 1 & 5 & 4 & 4 & 5 & 3 & 4 & 5 & 4 \\
\hline & $\begin{array}{l}\text { Reagavimas i } \\
\text { užklausas }\end{array}$ & 2 & 4 & 2 & 4 & 5 & 5 & 4 & 5 & 5 & 5 & 4 & 4 & 3 & 1 & 5 & 4 & 4 & 5 & 4 & 4 & 5 & 4 \\
\hline & Pagalba & 2 & 4 & 2 & 4 & 5 & 5 & 4 & 5 & 5 & 5 & 4 & 4 & 3 & 1 & 5 & 4 & 4 & 5 & 4 & 4 & 5 & 4 \\
\hline \multirow{3}{*}{ Kokybè } & Paslaugos & 4 & 4 & 5 & 1 & 5 & 5 & 5 & 5 & 3 & 5 & 5 & 5 & 5 & 3 & 5 & 5 & 5 & 4 & 5 & 5 & 5 & 5 \\
\hline & Informatyvumas & 5 & 5 & 5 & 2 & 5 & 3 & 5 & 5 & 5 & 5 & 5 & 5 & 3 & 1 & 5 & 5 & 5 & 5 & 5 & 5 & 5 & 5 \\
\hline & Reputacija & 5 & 5 & 5 & 3 & 4 & 3 & 5 & 5 & 5 & 5 & 5 & 5 & 2 & 3 & 5 & 5 & 4 & 5 & 5 & 5 & 5 & 5 \\
\hline Nuolaidos & $\begin{array}{l}\text { Paskutinès } \\
\text { minutės } \\
\text { pasiūlymai }\end{array}$ & 5 & 1 & 2 & 1 & 1 & 5 & 2 & 1 & 1 & 5 & 4 & 2 & 1 & 1 & 2 & 1 & 3 & 1 & 5 & 3 & 5 & 5 \\
\hline
\end{tabular}

Labai gerai įvertinta agentūrų R, S ir T tinklalapių estetika (nuo 4 iki 5), kompetentingumas (nuo 4 iki 5), bendradarbiavimas (nuo 4 iki 5) ir kokybè (nuo 4,7 iki 5). Agentūra T taiko nuolaidas (5), tačiau $\mathrm{R}$ ir $\mathrm{S}$ jų netaiko (nuo 1 iki 2).

Vertinant agentūrų U, V ir X tinklalapius, pabrěžiamas jų saugumas (nuo 4,8 iki 5), patogumas (nuo 4,9 iki 5), kompetentingumas (nuo 4 iki 5), bendradarbiavimas (5), tačiau estetika ivertinta nuo 3 iki 5 (yra stiliaus ir dizaino trūkumu).

Apibendrinant rezultatus galima teigti, kad daugeliui kelionių agentūrų tinklalapių būdingas saugumas (bendras vertinimo vidurkis - 4,1), kompetentingumas (4). Bendras patogumo vertinimo vidurkis - 3,8, todèl galima manyti, kad ne visų agentūrų tinklalapiai yra patogūs vartotojams. Tinklalapių estetika taip pat ịvertinta ne itin gerai (bendras vertinimo vidurkis - 3,4). Agentūrų A, C, M, N bendradarbiavimas įvertintas labai blogai (nuo 1 iki 3), tačiau kitų agentūru - pakankamai gerai (nuo 4 iki 5). Vertinant tinklalapiu kokybę, reikšmingų skirtumų nepastebėta (bendras vertinimo vidurkis - 4,5), todèl galima teigti, kad jų kokybė yra gera. Tačiau buvo pastebėta esminių skirtumų tarp visų kriterijų ir nuolaidų teikimo. Daugumoje tinklalapių nuolaidų skilties nèra arba teikiama mažai pasiūlymų (bendras vertinimo vidurkis - 2,5), labai išsiskiria tik keletas agentūrų $(A, F, J, T, V, X)$ - jų bendras vertinimo vidurkis yra 5 . 
Apibendrinant tyrimo rezultatus, nustatyti kelionių agentūrų tinklalapiai, kurie geriausiai ir prasčiausiai tenkina vartotojų poreikius. Šeštadalis įmonių (J, O, V, X) vartotojų poreikius tenkina geriausiai (bendras vertinimo vidurkis - nuo 4,2 iki 5), prasčiausiai - dvi agentūros ( $\mathrm{M}$ ir N), juc vertinimo vidurkiai - nuo 2,1 iki 2,5.

Tyrimo metu buvo išskirta viena svarbiausių kategoriju - tinklalapio saugumas. Saugumo svarbą pabrèžia ir daugelis kitų tyrëjų, mokslinių straipsnių autorių. Taip pat buvo išskirtos svarbiausios subkategorijos, susijusios su saugumu: kelionès paketo, kliento duomenu saugumas, informacijos patikimumas, grąžinimo garantas, apmokejjimo proceso saugumas ir paprastumas.

Kelionès paketo saugumas. Atlikto tyrimo duomenimis, Kauno miesto kelioniu agentūros užtikrina dideli kelionès paketo saugumą $(4,5)$. Kelionès paketas turi būti būtent toks, kokị užsisako klientas (pavyzdžiui, jeigu jis užsako 4 žvaigždučių viešbutị, tokiame ir turi būti apgyvendintas).

Kliento duomenu saugumas. Atlikto tyrimo duomenimis, Kauno miesto kelioniu agentūros gana gerai vertinamos dèl kliento duomenų saugumo $(4,2)$, nes užtikrina kreditinès kortelès saugumą, be kliento sutikimo neleidžia naudoti jo asmeninių duomenų (pavyzdžiui, telefono numerio, elektroninio pašto adreso).

Informacijos patikimumas. Atliktas tyrimas parodè, kad Kauno miesto kelionių agentūros atitinka informacijos patikimumo reikalavimus (teikia vartotojams tik teisingą informaciją, tęsi savo pažadus). Bendras šios subkategorijos vertinimo vidurkis $-4,7$.

Gražinimo garantas. Jị geriausiai galima užtikrinti tada, kai įmonè teikia ne paslaugas, o prekes - prekè gali būti laisvai grąžinta. Tačiau kelionių agentūros teikia paslaugas, todèl grąžinimo procesas šiek tiek sudètingesnis. Pasikeitus kliento planams, jis gali atgauti tik tam tikrą sumokètų pinigu dalị, atsižvelgiant i tai, kiek laiko liko iki išvykimo. Dėl to vartotojai dažai lieka nepatenkinti. Būtent šios priežastys lèmé gana žemą šio kriterijaus vertinimo vidurkị (3).

Apmokéjimo proceso saugumas ir paprastumas. Interneto erdvèje apmokèjimo procesas darosi vis paprastesnis: jis nepainus, vartotojui pateikiami aiškūs, konkretūs klausimai, nereikia ilgai laukti. Kelionių agentūros taip pat siekia užtikrinti paprastą apmokèjimo procesą. Klientai už paslaugas gali sumokèti dviem būdais: pirkti kreditine kortele iš karto arba rezervuoti ir sumokèti agentūroje. Atliktas tyrimas parodè, kad bendras šios subkategorijos vertinimo vidurkis yra 4,2.

Apibendrinant tinklalapiu vertinimo ypatumus galima teigti, kad ju saugumas yra svarbus kriterijus renkantis kelionę. Bendras Kauno kelionių agentūrų tinklalapių saugumo vertinimo vidurkis yra 4,5, taigi atitinka vartotojų lūkesčius.

Vertinant tinklalapio patogumą išskirtos svarbiausios subkategorijos: valdymas, greitis, prieinamumas, interaktyvumas, apmokèjimo procesas, nesuvaržytas darbo laikas, informacijos išdèstymas.

Valdymas turi būti nesudètingas, skatinti vartotojų lojalumą, užtikrinti paslaugu pirkimą. Atlikus tyrimą nustatyta, kad bendras Kauno kelionių agentūrų tinklalapių patogumo vertinimo vidurkis yra 3,7, taigi tinklalapiu valdymas yra vidutinio lygio.

Greitis tyrimo metu buvo îvertintas labai gerai (4,9), o tai daugiausia lèmé interneto greitis, kurị užtikrina pasirinktas interneto paslaugų tiekejjas. Vartotojams tai gana svarbus kriterijus, tačiau 
dauguma kelionių agentūrų taupydamos naudojasi minimaliomis interneto paslaugu galimybėmis ir taip apriboja savo tinklalapio duomenų srauto greiti.

Prieinamumas. Bendras paslaugu prieinamumo vertinimo vidurkis - 4,7. Tai rodo, kad Kauno miesto kelionių agentūrų tinklalapiuose informacija pateikiama aiškiai ir išsamiai, nesukeliant papildomų klausimų ir vartotojui palengvinant pasirinkimą. Šią informaciją vartotojai turi gauti be didelių pastangų. Paslaugu prieinamumas elektroninèje erdvėje turi būti užtikrintas ivvairiu poreikių vartotojams, nes jų norai, elgesys yra individualūs.

Interaktyvumas siejamas su operatyviais kelionių agentūros darbuotojų atsakymais i tinklalapio lankytojuc klausimus. Vartotojai tikisi atsakymo sulaukti greitai, o tai lemia paslaugu pardavimą. Atlikto tyrimo duomenimis, Kauno kelionių agentūrų tinklalapių interaktyvumo vertinimo vidurkis - 3,7. Taigi vidutiniškas šių tinklalapių interaktyvumas gali paskatinti vartotojus ieškoti ir kitų alternatyvų.

Apmokèjimo procesas. Pirkimas internetu - vienas populiariausių būdu tai atlikti savo aplinkoje. Jis yra patogus, nereikalauja didelių laiko ir ekonominių išlaidų, todèl tinklalapis turi turèti savo strategija, kaip tai padaryti kuo paprasčiau ir lengviau. Tyrimo duomenimis, apmokejjimo proceso patogumas Kauno kelionių agentūrų tinklalapiuose vertinamas labai prastai (bendras vidurkis -2,8). Tai rodo, kad apmokejjimo procesas nėra itin patogus vartotojams.

Nesuvaržytas darbo laikas. Tai galima traktuoti dvejopai: pirkti galima bet kuriuo metu (ši procesą ištisą parą užtikrina sistema, pagrista naujausiomis technologijomis), bet gauti konsultaciją - tik tam tikru (darbo) laiku. Bendras šios subkategorijos vertinimo vidurkis yra šiek tiek didesnis nei vidutinis - 3,8. Paprastai vartotojai randa laiko konsultuotis darbo metu, o pirkti gali bet kada, taigi didelių nepatogumų šiuo požiūriu nekyla.

Informacijos išdèstymas. Bendras informacijos išdèstymo Kauno kelionių agentūrų tinklalapiuose vertinimo vidurkis yra 3,5. Tai rodo, kad ne visuose tinklalapiuose informacijos išdėstymas tenkina vartotojų lūkesčius. Išdėstymo struktūra siejama su mygtukų vietos parinkimu, logišku išdèstymu. Kelionių agentūros turètų nuolat tobulinti informacijos išdèstymą tinklalapyje. Tai yra itin aktualu ne tik vartotojams, bet ir agentūroms, nes lemia jų paslaugų pirkimą.

Apibendrinant patogumo subkategorijų vertinimą galima teigti, kad svarbiausios iš ju yra valdymas, interaktyvumas, apmokejjimo procesas ir prieinamumas. Todèl kuriant tinklalapi labai svarbu atsižvelgti i vartotojo poreikius. Kauno kelionių agentūrų tinklalapių patogumas įvertintas kaip vidutinis (bendras vertinimo vidurkis - 3,8).

Estetika siejama su dizainu, vizualiu patrauklumu. Kelionių agentūrų tinklalapiams estetika yra ypač svarbu, nes išorinis vaizdas dažnai lemia didesni lankytojų skaičių, paslaugu pirkimą.

Dizainas dažnai asocijuojasi su spalvų derinimu, šrifto, spalvų parinkimu, teksto ar vaizdinès medžiagos išdėstymu. Kauno kelionių agentūrų tinklalapių vertinimo pagal dizainą vidurkis - 3,4. Tai rodo, kad agentūros savo tinklalapių dizainą turètų gerokai patobulinti.

Vizualus patrauklumas yra bendro vaizdo patrauklumas, kai visos vieno objekto (šiuo atveju - interneto puslapio) detalès yra pateiktos estetiškai. Vartotojai dažniausiai negali pasakyti, kodèl patinka tam tikras puslapis, bet jis būna mielas akiai, todèl i ji sugrižta. Atlikto tyrimo duomenimis, Kauno kelionių agentūrų tinklalapiams trūksta vizualaus patrauklumo (bendras vertinimo vidurkis $-3,3$ ). 
Kompetentingumui i̇vertinti buvo išskirta viena subkategorija - aptarnavimas. Gerą aptarnavimą rodo tinkamas komunikavimas, užsakymo sutarčių parengimas laiku, paslaugumas, patirtis, mokejjimas teisingai ir išsamiai patarti. Tačiau šioje srityje Kauno kelionių agentūroms reikia tobulèti, nes jų aptarnavimo vertinimo vidurkis - 3,5. Galima daryti prielaida, kad toki vertinimą lemia darbuotojų patirties trūkumas, didelis darbo krūvis ir kt.

Bendradarbiavimas yra vienas svarbiausių veiksnių, rodančių, koks svarbus organizacijai yra klientas. Bendradarbiavimui ịvertinti išskirtos keturios subkategorijos: bendravimas, personalizavimas, reagavimas į užklausas, pagalba.

Bendravimas. Tyrimo rezultatai parodè, kad Kauno kelionių agentūrų bendravimo su klientais vertinimo vidurkis - 4. Vadinasi, agentūros stengiasi bendrauti ir su esamais, ir su potencialiais klientais.

Personalizavimas. Daugelis autorių personalizavimą išskiria ne kaip pati svarbiausią interneto tinklalapių kokybės vertinimo kriterijų. Plačiaja prasme tai yra bendravimas su kiekvienu klientu individualiai: atsakoma i jo klausimus, patariama, stengiamasi suprasti jo lūkesčius, pasiūlomos alternatyvos atsižvelgiant i jo poreikius. Tiriant Kauno kelionių agentūrų tinklalapius nustatyta, kad i personalizavimą kreipiama per mažai dėmesio.

Reagavimas $\grave{l}$ užklausas gali būti siejamas su personalizavimu. Šis kriterijus neturi labai didelès reikšmės vartotojo apsisprendimui, tačiau vartotojas neturi jaustis ignoruojamas ir būtinai turi gauti atsakymą. Tyrimo rezultatai rodo gana aukštą reagavimo į užklausas vertinimo vidurki -4 . Dèl to galima teigti, kad Kauno kelionių agentūros dažniausiai atsako savo klientams ì rūpimus klausimus.

Pagalba siejama su išsamiu aiškinimu padedant pasirinkti kuri nors pasiūlymą ar padaryti tam tikrą veiksmą (apmokèti paslaugas, susirasti informaciją tinklalapyje ir kt.). Pagalbos Kauno kelionių agentūrų tinklalapiuose vertinimo vidurkis -4 .

Apibendrinant galima teigti, kad Kauno kelionių agentūros bendrauja su klientais, stengiasi jiems padèti rūpimais klausimais.

Kokybė yra gana svarbus veiksnys, lemiantis vartotojo apsisprendimą perkant paslaugas (ar prekes), taip pat organizacijos reputacija. Jei paslaugos (ar prekès) nebus kokybiškos, vartotojai ju daugiau nepirks. Kokybei ịvertinti išskirtos trys subkategorijos: paslaugos, informatyvumas, reputacija.

Paslaugos. Organizacija turi teikti kokybiškas paslaugas, atitinkančias vartotojų lūkesčius. Šiuo atveju labai svarbu optimalus paslaugos kainos ir kokybès santykis. Tyrimo metu Kauno kelionių agentūrų tinklalapiuose teikiamos paslaugos įvertintos kaip gana kokybiškos (vertinimo vidurkis - 4,5).

Informatyvumas - tai teisingai, aiškiai, išsamiai pateikta informacija apie paslaugas. Atlikus tyrimą nustatyta, kad Kauno kelionių agentūrų tinklalapių informatyvumas vertinamas gana gerai (vertinimo vidurkis $-4,5$ ).

Reputacija. Tyrimo duomenimis, Kauno kelionių agentūrų reputacija vertinama gana gerai (vertinimo vidurkis - 4,5). Tai rodo, kad agentūros dažniausiai nenuvilia savo klientų ir teikia paslaugas, atitinkančias jų poreikius ir elgseną interneto erdvèje. 
Apibendrinant galima teigti, kad Kauno kelionių agentūros teikia kokybiškas paslaugas (bendras vertinimo vidurkis - 4,5).

Nuolaidos dažnai nèra labai svarbus kriterijus, jei organizacija atitinka bent keletą kitų. Noredama pritraukti ar išlaikyti vartotojus, organizacija, teikdama kokybiškas paslaugas, turi orientuotis ne tik $\mathfrak{i}$ ší, bet ir $\mathfrak{i}$ kitus kriterijus. Nuolaidoms ivertinti išskirta paskutinès minutès pasiūlymu subkategorija. Kelionių agentūrų tinklalapiuose paskutinès minutès pasiūlymai paprastai teikiami atskiroje skiltyje. Visada yra vartotojų, mėgstančių nuolaidas, kurios dažniausiai ir paskatina juos pirkti. Tyrimo metu daugumoje Kauno kelionių agentūrų tinklalapių nuolaidų nebuvo siūloma (vertinimo vidurkis - 2,5). Tikètina, tai lèmé sezonas, kuriuo nuolaidos netaikomos.

Apibendrinant Kauno kelionių agentūrų tinklalapių vertinimo rezultatus galima teigti, kad svarbiausi vertinimo kriterijai yra saugumas, kompetentingumas ir kokybė.

Vertinant agentūras pagal bendrą visų kategorijų vidurkị pastebėta, kad trijų kelionių agentūrų vertinimo vidurkiai yra nuo 4,2 iki 5. Labiausiai vartotojų poreikių neatitinka dvi agentūros (bendras vertinimo vidurkis - nuo 2,1 iki 2,5).

Geriausiai buvo ivvertinta 13 subkategorijų: kelionès paketas, kliento duomenų saugumas, informacijos patikimumas, apmokejjimas, greitis, prieinamumas, aptarnavimas, bendravimas, reagavimas i užklausas, pagalba, paslaugos ir informacijos kokybė bei reputacija. Jų vertinimo vidurkis yra ne mažesnis kaip 4. Tai rodo, kad Kauno miesto kelionių agentūrų tinklalapiuose siūlomos paslaugos atitinka vartotojų lūkesčius ir poreikius.

Vertinant tinklalapius pagal Kauno kelionių agentūrų veiklos pobūdi nustatyta, kad dauguma jų parduoda kelionių (pažintinių, poilsinių, egzotinių) paketus, beveik visos kelionių agentūros užsakinèja transporto bilietus. Agentūra, kuri organizuoja verslo keliones, dažniausiai orientuojasi i tą vieną veiklos formą. Apibendrinant galima teigti, kad daugumos Kauno miesto kelionių agentūru $(\mathrm{J}, \mathrm{K}, \mathrm{O}, \mathrm{S}, \mathrm{T}, \mathrm{U}, \mathrm{V}, \mathrm{X})$ veikla tenkina vartotoju poreikius (bendras vertinimo vidurkis - nuo 4 iki 5). Prasčiausiai šiuo aspektu įvertintos kelionių agentūros $\mathrm{C}$ ir N.

\section{IŠVADOS}

Svarbiausi veiksniai, turintys itakos vartotoju pasirinkimui pirkti internetu, yra interneto tinklalapių patogumas, saugumas, aptarnavimas, valdymas, dizainas ir bendravimas.

Kauno miesto kelionių agentūrų tinklalapiuose siūlomos paslaugos geriausiai vertinamos saugumo, kompetentingumo, kokybès, o prasčiausiai - estetikos ir nuolaidų teikimo aspektais. Gana gerai vertinama patogumas ir bendradarbiavimas.

Tik šeštadalio tirtų Kauno kelionių agentūrų tinklalapiai vertinami aukščiausiais balais, o didžiosios daugumos vertinimo vidurkiai varijuoja pagal pasiūlos kriteriju.

Tyrimo rezultatai pagal veiklos pobūdi parodè, kad daugelis Kauno miesto kelionių agentūrų parduoda kelionių paketus, todèl labai svarbūs kriterijai yra patikimumas (kelionès paketo) ir estetika. 


\section{LITERATŪRA}

1. Bakanauskas, A., Liesionis, V. (2008). Elektroninis marketingas. Kaunas: VDU leidykla.

2. Bukhari, F. M. S. (2013). The antecedents of travelers' e-satisfaction and intention to buy airline tickets online. Journal of Enterprise Information Management, 26 (6), 626-628.

3. Castaneda, A. J., Farias, M. D., Rodrigues, A. M. (2008). Antecedents of internet acceptance and use as an information sourse by tourists. Online Information Review, 33 (3), 551. Interneto prieiga: http://www.emeraldinsight.com/journals.htm?articleid=1796005\&show=abstract [žiūreta 2014-03-18].

4. Constantinides, E. (2004). Influencing the online consumer's behavior: the Web experience. Journal Internet Research, 14 (2), 111-117. Interneto prieiga:

http://www.emeraldinsight.com/journals.htm?issn=10662243\&volume=14\&issue $=2 \&$ articleid $=1509308$ \&show=html [žiūrèta 2014-03-21].

5. Davidavičienė, V., Tolvaišas, J. (2011). Elektroninės prekybos interneto svetainių Lietuvoje vertinimas. Informacijos mokslai, 55, 103-116.

6. Guseva, N. (2010). Elektroninès komercijos kokybès kriterijų identifikavimas ir analizè. Verslas: teorija ir praktika, 11 (2), 96-106. Interneto prieiga: http://www.btp.vgtu.lt/index.php/btp/article/viewFile/btp.2010.11/11 [žiūrèta 2014-03-21].

7. Jalilvand, R. M., Ebrahimi, A., Samiei, N. (2013). Electronic word of mouth effects on tourists' attitudes toward Islamic destination and travel intention: an empirical study in Iran. Social and Behavioral Science, 81, 484-486. Interneto prieiga: http://www.sciencedirect.com/science/article/pii/S1877042813015322 [žiūrèta 2014-02-10].

8. Kardelis, K. (2002). Moksliniu tyrimu metodologija ir metodai. Kaunas: Judex.

9. Komskienè, D., Kotkevičiūtè, A. (2014). Turistų poreikių dermès elektroninei erdvei vertinimas. Mokslas ir praktika: aktualijos ir perspektyvos. Moksliniu straipsniu rinkinys (pp. 101-109). Kaunas: Lietuvos sporto universitetas.

10. Law, R. (2007). How do the preference of online buyers and browsers differ on the design and content of travel websites. International Journal of Contemporary Hospitality Management, 20 (4), 395-396. Interneto prieiga: http://www.emeraldinsight.com/journals.htm?articleid=1728364 [žiūrèta 2014-03-18].

11. Liu, T. M. (2012). Perceived benefits, perceived risk, and trust Influences on consumers' group buying Behaviour [elektroninis išteklius]. Asia Pacific Journal of Marketing and Logistics, 25 (2), 228-247.

12. Martin, S., Camarero, C. (2008). How perceived risk affects online buying. Emerald Online Information Review, Vol. 33, No 4, 629-654.

13. Ozen, H., Engizek, N. (2013). Shopping online without thinking: being emotional or rational? Asia Pacific Journal of Marketing and Logistics, 26 (1), 80. Interneto prieiga: file:///C:/Users/VK/Downloads/17102252\%20(1).pdf [žiūrèta 2014-03-20].

14. Trocchia, J. P., Janda, S. (2003). How do consumers evaluate Internet retail service quality? Journal of Services Marketing, 17 (3), 244. Interneto prieiga: file:///C:/Users/VK/Downloads/855975.pdf [žiūrèta 2014-01-27].

15. Tucker, P. S. (2008). E-commerce standart user interface: an E-meniu system. Journal of Industrial Management \& Data Systems, 108 (8), 1012. Interneto prieiga:

file:///C:/Users/VK/Downloads/1747081\%20(1).pdf [žiūrèta 2014-01-18].

16. Žydžiūnaite, V. (2005). Qualitative diagnostics of professional identity development in vocational education and training: congruences and disconnections. Education-Line. [Serial Online], 1-20. Interneto prieiga: http://www.leeds.ac.uk/educol/docu- ments/142829.htm [žiūrèta 2014-01-27].

17. Žydžiūnaitė, V. (2007). Tyrimo dizainas: struktūra ir strategijos: mokomoji knyga. Kaunas: Technologija. 